\title{
PENGARUH PENGUNGKAPAN TANGGUNG JAWAB SOSIAL PERUSAHAAN TERHADAP KINERJA KEUANGAN
}

\author{
Elvira Luthan \\ virasmi@yahoo.com \\ Sri Amelia Rizki \\ Sri Dewi Edmawati \\ Fakultas Ekonomi dan Program Studi Magister Sains Akuntansi \\ Universitas Andalas
}

\begin{abstract}
The aim of this research is to know: (1) The influence of the corporate social responsibility disclosure (CSR) to financial performance, (2) How the influence of CSR to two proxies of financial performance, in this case the ROA and Tobins' $Q$. (3) The influence of characteristic of the company as the moderating variable in relations between corporate social responsibility and financial performance. This research used multiple regression analysis. The research samples are 45 manufacturing companies listed in the Indonesia Stock Exchange (BEI) during 20112014. The samples are selected using purposive sampling technique with predetermined criteria. Age, size of the board of commissioners and company size is used as a proxy of the characteristics of the company, while return on assets (ROA) and Tobin's $Q$ as proxy of the company financial performance. The hypothesis test results showed CSR disclosure effect significantly to financial performance as measured by ROA, on the financial performance is measured by tobin's $Q$ no effect significant. The interaction test results showed age can increase the effect of (to moderate) CSR disclosure on financial performance as measured by ROA. While size of the board of commissioners and company size is not able to moderate the effect of CSR disclosure on financial performance both measured by ROA or tobin's $Q$.
\end{abstract}

Key words : CSR, ROA, Tobin's Q, Firm Characteristic

\begin{abstract}
ABSTRAK
Tujuan dari penelitian ini adalah untuk mengetahui : (1) Pengaruh pengungkapan tanggung jawab sosial perusahaan (Corporate Social Responsibility/CSR) terhadap kinerja keuangan perusahaan (2) Pengaruh karakteristik perusahaan sebagai variabel moderating dalam hubungan antara pengungkapan tanggung jawab sosial perusahaan dan kinerja keuangan perusahaan. Penelitian ini menggunakan analisis regresi berganda. Sampel penelitian adalah 45 perusahaan manufaktur yang terdaftar di Bursa Efek Indonesia (BEI) periode 2011-2014. Sampel penelitian dipilih dengan teknik purposive sampling dengan kriteria yang telah ditetapkan. Umur perusahaan, ukuran dewan komisaris dan ukuran perusahaan digunakan sebagai proksi dari karakteristik perusahaan, sedangkan return on asset (ROA) dan tobin's $Q$ sebagai proksi dari kinerja keuangan perusahaan. Hasil uji hipotesis menunjukkan pengungkapan tangung jawab sosial perusahaan berpengaruh secara signifikan terhadap kinerja keuangan yang diukur dengan ROA, sedangkan terhadap kinerja keuangan yang diukur dengan tobin's $Q$ tidak berpengaruh signifikan. Hasil uji interaksi menunjukkan umur perusahaan mampu meningkatkan pengaruh (memoderating) pengungkapan tanggung jawab sosial perusahaan terhadap kinerja keuangan yang diukur dengan ROA. Sementara itu ukuran dewan komisaris dan ukuran perusahaan tidak mampu memoderating dalam hubungan antara pengungkapan tanggung jawab sosial perusahaan dan kinerja keuangan baik yang diukur dengan ROA atau tobin's $Q$.
\end{abstract}

Kata kunci : CSR, ROA, Tobin's Q, Firm Characteristic. 


\section{PENDAHULUAN}

Pada masa kini untuk bisa bertahan hidup suatu perusahaan harus peduli dengan lingkungan tempat perusahaan beroperasi. Kepedulian perusahaan ini diimplementasikan dengan CSR yang dilakukan perusahaan. Konsep CSR berkembang secara ekstrim dan dinamis. Secara umum CSR adalah cara sebuah perusahaan dalam mencapai keseimbangan atau integrasi dari ekonomi, lingkungan serta permasalahan sosial dan dalam waktu yang sama dapat memenuhi harapan dari para shareholder maupun stakeholder (Luthan, 2010). CSR yang sering dianggap inti dari etika bisnis adalah bahwa perusahaan tidak hanya mempunyai kewajiban-kewajiban ekonomi dan legal (artinya kepada pemengang saham atau shareholder) tetapi juga kewajiban-kewajiban terhadap pihak-pihak lain yang berkepentingan (stakeholder) yang jangkauannya melebihi kewajiban-kewajiban di atas. (WBC SD, 2008; Anwar et al., 2010; Saleh et al., 2008). Implikasi dari pertanggung jawaban sosial adalah menciptakan standar kehidupan yang lebih tinggi, dengan menyisihkan sebagian keuntungan (profitability) perusahaan untuk para stakeholders-nya baik yang internal maupun yang eksternal dari perusahaan. Aktivitas CSR yang dilakukan perusahaan akan diungkapkan oleh perusahaan melalui laporan tahunannya. Pengungkapan CSR mengacu kepada tanggung jawab sebuah entitas terhadap semua stakeholders, termasuk masyarakat secara umum dan lingkungan fisik tempat entitas beroperasi. Banyak alasan mendukung pendapat mengapa kalangan dunia usaha harus merespons dan mengembangkan isu CSR sejalan dengan operasi usahanya (Daniri, 2008), diantaranya adalah: Pertama, perusahaan adalah bagian dari masyarakat dan oleh karenanya wajar bila perusahaan memperhatikan kepentingan masyarakat. Kedua, kalangan bisnis dan masyarakat sebaiknya memiliki hubungan yang bersifat simbiosis mutualisme. Ketiga, kegiatan tanggung jawab sosial merupakan salah satu cara untuk meredam atau bahkan menghindari konflik sosial.

Jadi dalam gagasan CSR bukan hanya dihadapkan pada pertanggung jawaban satu sisi (singel bottom line) yaitu nilai perusahaan yang direfleksikan ke dalam aspek keuangan, tapi juga harus berpijak pada triple bottom line (TBL) yaitu selain finansial juga kinerja sosial dan lingkungannya (Hubbard, 2009; Morland, 2006).

Kepedulian pemerintah Indonesia terhadap CSR dapat dilihat dengan dikeluarkannya Undang-Undang Nomor 40 tahun 2007 tentang Perseroan Terbatas. Tujuan dikeluarkannya UU ini adalah untuk mengatur keberadaan dan pedoman perusahaan dalam menjalankan roda perusahaannya serta mencegah terjadinya pertumbuhan ekonomi yang menyimpang. Dalam pasal ini pemerintah mewajibkan korporasi yang berhubungan dengan sumber daya alam untuk menganggarkan sejumlah dananya dalam upaya melakukan program CSR yang pelaksanaannya dilakukan dengan memperhatikan kepatutan dan kewajaran.

Disamping itu, pasar modal Indonesia juga telah mendukung pelaksanaan dan pelaporan CSR melalui penerapan indeks sejak tahun 2008. PT Bursa Efek Indonesia (BEI) bekerja sama dengan Yayasan Keanekaragaman Hayati Indonesia (KEHATI) yaitu sebuah yayasan yang bergerak di bidang pelestarian dan pemanfaatan keanekaragaman hayati, menerbitkan indeks harga saham yang mengacu pada tata cara Sustainable and Responsible Investment (SRI) yang diberi nama indeks SRI-KEHATI. Indeks ini memasukkan kategori saham emiten yang telah mempraktekkan CSR dengan mempertimbangkan enam aspek fundamental SRI-KEHATI sebagai kriteria pemeringkatan, yakni lingkungan, pengembangan masyarakat, tata kelola perusahaan, hak asasi manusia, perilaku bisnis dan prinsip ketenaga kerjaan (Yayasan Kehati, 2015). Sejumlah penelitian tentang manfaat CSR telah banyak dilakukan. Hasil dari penelitian tersebut membuktikan bahwa 
CSR berdampak positif terhadap profitabilitas perusahaan maupun imbal hasil saham (Steiner dan Steiner, 2006; Orlitzky et al., 2003). Alasan utama para peneliti tersebut adalah untuk membuktikan bahwa manfaat finansial perusahaan dengan berinvestasi dalam CSR dapat melebihi biaya yang dikeluarkan (McBarnett et al., 2007). Hal ini disebabkan, dampak investasinya bermanfaat di dalam meningkatkan moral karyawan, goodwill, memperbaiki hubungan dengan perbankan, investor, dan pemerintah dan mendapatkan akses modal lebih baik, sehingga masing-masing pada akhirnya akan memperbesar kinerja perusahaan. Alasan selanjutnya, dalam pandangan masyarakat, perusahaan yang melakukan aktivitas CSR dianggap memiliki sumber daya yang superior karena hanya perusahaan yang cukup danalah yang mampu melakukannya.

Kinerja perusahaan merupakan suatu gambaran tentang kondisi keuangan suatu perusahaan, yang mencerminkan prestasi kerja dalam periode tertentu. Salah satu ukuran kinerja perusahaan adalah kinerja keuangan. Kinerja keuangan adalah gambaran kondisi keuangan perusahan pada suatu periode tertentu baik menyangkut aspek penghimpunan dana manapun penyaluran dana, yang biasanya diukur dalam indikator kecukupan modal, likuiditas, dan profitabilitas (Jumingan, 2006). Menurut Sutrisno (2012) kinerja keuangan perusahaan merupakan prestasi yang dicapai perusahaan dalam suatu periode tertentu yang mencerminkan tingkat kesehatan perusahaan tersebut.

Selanjutnya, Al-Tuwaijri et al. (2004) dan Sutrisno (2012), menyatakan kinerja keuangan perusahaan dapat dilihat dalam dua pengukuran yaitu Accounting-based measurement, seperti ROA, ROE dan lain lain, serta market-based measure), seperti kapitalisasi pasar, Tobin's Q. Tiap-tiap dasar pengukuran kinerja keuangan ini memiliki kelebihan dan kelemahan. Penelitian ini menggunakan kedua ukuran kinerja keuangan agar dapat diperbandingkan.
Dampak dari pengungkapan aktivitas sosial perusahaan tergantung pada karakteristik perusahaan. Secara umum karakteristik operasi perusahaan yang menghasilkan dampak sosial yang tinggi akan menuntut pemenuhan pengungkapan tanggung jawab sosial yang lebih tinggi pula. Karakteristik perusahaan yang digunakan dalam beberapa penelitian biasanya adalah umur perusahaan, jenis perusahaan, dan ukuran perusahaan. Dalam penelitian ini karakteristik perusahaan diperlakukan sebagai variabel moderating karena dianggap dapat mempengaruhi pengaruh pengungkapan CSR terhadap kinerja keuangan. Variabel moderating adalah variabel independen yang akan memperkuat atau memperlemah hubungan antara variabel independen lainnya terhadap variabel dependen (Ghozali, 2012).

Berdasarkan review dari beberapa penelitian sebelumnya maka penulis tertarik untuk mengkaji lagi pengungkapan CSR terhadap kinerja keuangan, dengan menggunakan sampel sektor industri manufaktur yang terdaftar di Bursa Efek Indonesia (IDX). Penelitian ini berbeda dengan penelitian sebelumnya dalam hal dasar pengukuran kinerja keuangan yang digunakan adalah accounting dan market based measured. Hasil analisis akan membandingkan kedua kinerja diatas, mana yang paling dipengaruhi oleh pengungkapan CSR. Hasil analisis bermanfaat untuk masukan bagi pemerintah, dewan pembuat standar, praktisi bisnis dan akademisi dalam hal pengembangan teori.

\section{TINJAUAN TEORETIS \\ Teori-teori Dasar}

Teori stakeholders merupakan salah satu teori yang mendasari perusahaan melakukan CSR. Teori ini menjelaskan bagaimana manajemen perusahaan memenuhi atau mengelola harapan para stakeholder. Gray, Kouhy dan Adams (dalam Ghozali dan Chariri, 2007) mengatakan bahwa: Kelangsungan hidup perusahaan tergantung pada dukungan stakeholder dan dukungan tersebut harus dicari sehingga aktivitas 
perusahaan adalah untuk mencari dukungan tersebut. Makin powerful stakeholders, makin besar usaha perusahaan untuk beradaptasi. Pengungkapan sosial dianggap sebagai bagian dari dialog antara perusahaan dengan stakeholders-nya.

Stakeholders merupakan pihak-pihak yang berkepentingan pada perusahaan yang dapat mempengaruhi atau dapat dipengaruhi oleh aktivitas perusahaan. Organisasi memiliki banyak stakeholders seperti karyawan, masyarakat, negara, supplier, pasar modal, pesaing, badan industri, pemerintah asing dan lain-lain. Stakeholders pada dasarnya dapat mengendalikan atau memiliki kemampuan untuk mempengaruhi pemakaian sumber-sumber ekonomi yang digunakan perusahaan.

Legitimacy theory menjelaskan organisasi secara kontinu akan beroperasi sesuai dengan batas-batas dan nilai yang diterima oleh masyarakat di sekitar perusahaan dalam usaha untuk mendapatkan legtimasi. Guthrie dan Parker (1989) menyatakan bahwa perusahaan beroperasi dalam sebuah lingkungan sosial melalui kontrak sosial, dimana terdapat kesepakatan untuk memberikan berbagai tindakan sosial yang sesuai agar ia dapat melakukan tujuan-tujuannya. Jadi kegiatan sosial perusahaan dapat menjadi salah satu sarana untuk mendapatkan legitimasi di masyarakat. Teori legitimasi ini sangat bermanfaat daam menganalisis perilaku organisasi.

Dowling dan Peffer (dalam Ghozali dan Chariri, 2007) mengatakan: Legitimasi adalah hal yang penting bagi organisasi, batasan-batasan yang ditekankan oleh normanorma dan nilai-nilai sosial, reaksi tehadap batasan tersebut mendorong pentingnya analisis perilaku organisasi dengan memperhatikan lingkungan.

Norma perusahaan selalu berubah mengikuti perubahan dari waktu ke waktu sehingga perusahaan harus mengikuti perkembangannya. Usaha perusahaan mengikuti perubahan untuk mendapatkan legitimasi merupakan suatu proses yang dilaku- kan secara berkesinambungan (Kolk, 2008). Proses untuk mendapatkan legitimasi berkaitan dengan kontrak sosial antara yang dibuat oleh perusahaan dengan berbagai pihak masyarakat. Hal ini sesuai dengan pernyataan Ghozali dan Chariri (2007) bahwa yang mendasari teori legitimasi adalah kontrak sosial yang terjadi antara persuahaan dengan masyarakat dimana perusahaan beroperasi dan menggunakan sumber ekonomi.

\section{Rerangka Pemikiran dan Pengembangan Hipotesis}

Variabel penelitian ini terdiri dari tiga jenis variabel yaitu variabel dependen yang berupa kinerja keuangan yang diproksikan dengan ROA untuk kinerja keuangan berbasis akuntansi dan Tobin's $Q$ untuk ukuran kinerja keuangan yang berbasis pasar. Variabel independen dalam penelitian ini berupa pengungkapan CSR, dan karateristik perusahaan yang juga berfungsi sebagai variable moderating. Berikut hubungan antar variabel penelitian Gambar 1.

\section{Pengaruh Pengungkapan Tanggung Jawab Sosial Perusahaan Terhadap Kinerja Keuangan Perusahaan.}

Berdasarkan teori stakeholder ada hubungan positif antara tanggung jawab sosial perusahaan (CSR) dan kinerja keuangan atau Corporate Financial Performance (CFP). Alasannya, kepuasan berbagai kelompok stakeholders bisa merupakan alat untuk meningkatkan kinerja keuangan organisasi (Saleh et al., 2008). Hal ini konsisten dengan hasil analisis meta yang dilakukan Allouche dan Laroche (2005), dimana kinerja sosial perusahaan berhubungan dengan kinerja keuangan. Mereka menyimpulkan bahwa hubungan kedua variabel tersebut bersifat resiprokal dan simultan.

Allouche dan Laroche (2005) menggunakan analisis statistik multivariate dan regresi (yang dikenal dengan meta regresi) terhadap 373 observasi dari 82 hasil studi. 


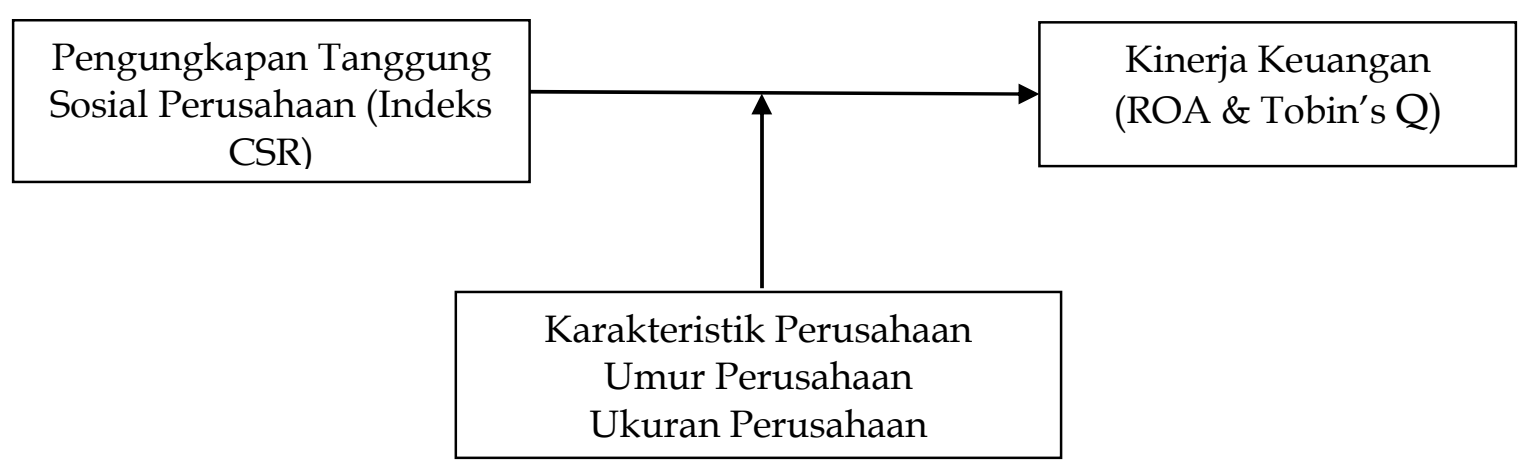

Sumber: Diolah sendiri dari berbagai sumber

\section{Gambar 1 \\ Rerangka Konseptual}

Hasil studi Allouche dan Laroche (2005) konsisten dengan $\mathrm{Wu}$ (2006), yakni kinerja sosial berpengaruh positif terhadap kinerja finansial perusahaan. Selanjutnya analisis meta yang dilakukan oleh $\mathrm{Wu}$ (2006) terhadap hubungan CSR, kinerja keuangan dan ukuran perusahaan menyimpulkan bahwa ukuran kinerja pasar (market based performance) merupakan prediktor yang lemah dibandingkan dengan kinerja keuangan, seperti profitabilitas, ROA dan pertumbuhan (growth). Meta analisis ini juga menyimpulkan bahwa biaya untuk aktivitas CSR tertutupi dengan manfaat aktivitas CSR tersebut, terutama berkaitan dengan moral karyawan dan produktivitas. (Wu, 2006).

Penelitian empiris yang dilakukan di Indonesia tentang CSR relatif masih sedikit. Diantaranya hanya mengkaji tentang kandungan informasi jika perusahaan mengungkapkan aktivitas CSR nya. Penelitian Yosefa dan Wondabio (2007) menggunakan sampel perusahaan yang listing di BEJ dan mengindikasikan bahwa investor mengapresisasi informasi CSR yang diungkapkan dalam laporan tahunan perusahaan. Penelitian yang dilakukan di BEJ oleh Lukas dan Basuki (2014) membuktikan bahwa kinerja lingkungan berpengaruh positif dan signifikan terhadap kinerja ekonomi. Penelitian CSR di Indonesia secara umum menggunakan pengungkapan CSR dalam laporan tahunan perusahaan.
Penilaian kinerja dengan menggunakan rasio profitabilitas (misalnya, ROA), merupakan indikator kinerja fundamental perusahaan yang mewakili kinerja manajemen. Sesuai dengan perkembangan model penelitian bidang manajemen keuangan, umumnya dimensi profitabilitas memiliki hubungan kausalitas terhadap nilai perusahaan. Nilai perusahaan secara konsep untuk perusahaan yang go public dapat dijelaskan oleh nilai yang ditentukan oleh harga saham yang diperjual belikan di pasar modal. Salah satu ukuran penilaian kinerja ini adalah Tobin's Q.

Penelitian yang dilakukan oleh Choi et al. (2010), melihat pengaruh hubungan antara CSR dan kinerja keuangan perusahaan, indikator untuk kinerja digunakannya adalah ROE, ROA dan Tobin's Q. Hasil studinya terdapat hubungan positif dan signifikan antara kinerja keua- ngan perusahaan dan stakeholder-weigthted CSR index, tapi tidak adanya hubungan terhadap Equal-weighted CSR index.

Berdasarkan uraian diatas maka dapat dirumuskan hipotesisnya sebagai berikut:

$\mathrm{H}_{1 . a}$ : Pengungkapan tanggung jawab sosial perusahaan berpengaruh terhadap kinerja keuangan (ROA).

$\mathrm{H}_{1 . \mathrm{b}}$ : Pengungkapan tanggung jawab sosial perusahaan berpengaruh terhadap kinerja keuangan (Tobin's Q). 
Pengaruh Umur Perusahaan Dalam Hubungan Pengungkapan Tanggung Jawab Sosial Perusahaan Dan Kinerja Keuangan.

Umur perusahaan dapat menunjukkan bahwa perusahaan masih tetap eksis dan mampu bersaing. Dengan demikian umur perusahaan dapat dikaitkan dengan kinerja keuangan suatu perusahaan. Jika suatu perusahaan mempunyai kinerja keuangan yang baik maka perusahaan tersebut akan dapat menjaga kelangsungan hidup usahanya (Luthan, 2010). Menurut Erica et al. (2011), umur perusahaan sangat mempengaruhi pelaporan keuangan perusahaan, karena berkaitan dengan pengembangan dan pertumbuhan perusahaan tersebut.

Umur perusahaan merupakan hal yang dipertimbangkan investor dalam menanamkan modalnya. Ketika sebuah perusahaan berkembang dan para akuntannya belajar lebih banyak masalah pertumbuhan, menyebabkan penundaan yang luar biasa dapat diminimalisasikan. Akibatnya perusahaan mapan yang memiliki umur lebih tua cenderung lebih terampil dalam pengumpulan, pemprosesan dan menghasilkan informai ketika diperlukan karena lebih berpengalaman belajar. Semakin lama perusahaan beroperasi, maka semakin memungkinkan perusahaan berada dalam keadaan operasi dan kinerja keuangan yang kokoh. Hal ini akan berimplikasi pada meningkatnya kinerja perusahaan dari penilaian pasar. Berdasarkan uraian diatas maka dapat dirumuskan hipotesisnya sebagai berikut:

$\mathrm{H}_{2 . \mathrm{a}}$ : Umur perusahaan mempengaruhi hubungan pengungkapan tanggung jawab sosial perusahaan dengan kinerja keuangan (ROA).

$\mathrm{H}_{2 . \mathrm{b}}$ : Umur perusahaan mempengaruhi hubungan pengungkapan tanggung jawab sosial perusahaan dengan kinerja keuangan (Tobin's Q)

Pengaruh Ukuran Dewan Komisaris Dalam Hubungan Pengungkapan Tanggung Jawab Sosial Perusahaan Dan Kinerja Keuangan.
Dewan komisaris dalam suatu perusahaan lebih ditekankan pada fungsi monitoring dari implementasi kebijakan direksi. Peran komisaris ini diharapkan akan meminimalisir permasalahan agensi yang timbul antara dewan direksi dengan pemegang saham, oleh karena itu dewan komisaris seharusnya dapat mengawasi kinerja dewan direksi sehingga kinerja yang dihasilkan sesuai dengan kepentingan pemegang saham. Dewan komisaris memegang peranan penting dalam mengarahkan strategi dan mengawasi jalannya perusahaan serta memastikan bahwa para manajer benar-benar meningkatkan kinerja perusahaan sebagai bagian dari pada pencapaian tujuan perusahaan. Lukas dan Basuki (2014) menyatakan bahwa semakin besar jumlah anggota dewan komisaris, maka akan semakin mudah untuk mengendalikan CEO dan monitoring yang dilakukan akan semakin efektif. Dikaitkan dengan pengungkapan tanggung jawab sosial, maka tekanan terhadap manajemen juga akan semakin besar untuk mengungkapkan aktivitas CSR. Jika manajemen melakukan pengungkapan tanggung jawab sosial perusahaan dengan baik maka hal ini akan berdampak terhadap kinerja keuangan perusahaan tersebut.

Adams dan Mehran (2005) menggunakan Tobin's $Q$ dalam menguji hubungan antara struktur dewan yang dilihat dari ukuran dan komposisi dewan dengan kinerja yang menggunakan $32 \mathrm{BCHs}$ (Bank Holding Companies) terbesar yang listing di New York Stock Exchange selama tahun 19861999. Penelitian tersebut menemukan bahwa bank dengan dewan yang lebih banyak mempunyai kinerja yang tidak jelek. Valentina (2013) menggunakan Market to Book Ratio dan Tobin's $Q$ dalam menilai hubungan antara ukuran dewan dan kinerja perbankan di BEI. Hasilnya memperlihatkan bahwa ukuran dewan tidak mepunyai pengaruh terhadap kinerja bank. Berdasarkan uraian diatas maka dapat diumuskan hipotesisnya sebagai berikut: 
$\mathrm{H}_{3 . \mathrm{a}}$ : Ukuran dewan komisaris mempengaruhi hubungan pengungkapan tanggung jawab sosial perusahaan dengan kinerja keuangan (ROA).

$\mathrm{H}_{3 \mathrm{~b}}$ : Ukuran dewan komisaris mempengaruhi hubungan pengungkapan tanggung jawab sosial perusahaan dengan kinerja keuangan (Tobin's Q).

\section{Pengaruh Ukuran Perusahaan Dalam Hubungan Pengungkapan Tanggung Jawab Sosial Perusahaan Dan Kinerja Keuangan.}

Penelitian yang dilakukan oleh $\mathrm{Wu}$ (2006) (dalam Luthan, 2010) terhadap hubungan CSR, kinerja keuangan dan ukuran menyimpulkan bahwa ukuran kinerja pasar (market-based performance) merupakan prediktor yang lemah dibandingkan dengan kinerja keuangan, seperti profitabilitas, ROA dan pertumbuhan (growth). Penelitian ini menyimpulkan bahwa biaya untuk aktivitas CSR tertutupi dengan manfaat dilakukannya CSR tersebut terutama berkaitan dengan moral karyawan dan produktivitas, sedangkan size tidak berpengaruh terhadap CSR maupun kinerja keuangan. Mungkin hal ini disebabkan masih sedikitnya studi yang mengkaji tentang hubungan size perusahaan dan kinerja sosial $(\mathrm{Wu}, 2006$ dalam Luthan, 2010). Kinerja perusahaan memperlihatkan kemampuan perusahaan untuk memberikan keuntungan dari asset. Besar atau kecilnya asset yang dimiliki perusahaan dapat menggambarkan ukuran dari asset yang dimiliki, menjadi salah satu indikator penilaian kinerja keuangan suatu perusahaan. Ini menjadi landasan bagi para peneliti untuk melihat seberapa besar pengaruh dari ukuran perusahaan terhadap kinerja keuangan. Ukuran perusahaan dapat berpengaruh terhadap kinerja keuangan telah dibuktikan secara empiris oleh peneliti an yang dilakukan oleh Wright et al. (2009); Ramasamy et al. (2005). Mereka menemukan bukti bahwa ukuran perusahaan berpengaruh positif signifikan terhadap kinerja keuangan perusahaan. Ukuran perusahaan dalam penelitian ini berpengaruh pada kemampuan finansialnya untuk mendanai investasi pada sumber daya manusia, pemberian gaji yang cukup tinggi sehingga memuaskan pegawainya, memberikan training yang meningkatkan kemampuan pegawai, dan mampu membangun jaringan system informasi yang baik dan efisien untuk membantu operasional perusahaan. Berdasarkan uraian diatas maka dapat diumuskan hipotesisnya sebagai berikut:

$\mathrm{H}_{4 . a}$ : Ukuran perusahaan mempengaruhi hubungan pengungkapan tanggung jawab sosial perusahaan dengan kinerja keuangan (ROA).

$\mathrm{H}_{4 . b}$ : Ukuran perusahaan mempengaruhi hubungan pengungkapan tanggung jawab sosial perusahaan dengan kinerja keuangan (Tobin's Q).

\section{METODE PENELITIAN}

Penelitian ini merupakan studi empiris yang dilakukan untuk mendeskripsikan praktek pengungkapan CSR melalui laporan tahunan (annual repeort) pada perusahaan manufaktur yang terdaftar di BEI. Berikut penjelasan atas metode penelitian yang digunakan: Objek Penelitian adalah Pengungkapan CSR, Kinerja Keuangan, Ukuran Perusahaan, Ukuran Dewan Komisaris, Umur Perusahaan. Populasi Penelitia yaitu Perusahaan manufaktur yang terdaftar di Bursa Efek Indonesia (BEI) periode 20112014. Jenis Penelitian yang digunakan Eksplanatori verifikatif, untuk mendapatkan kejelasan fenomena yang terjadi secara empiris dan berusaha mendapatkan jawaban hubungan kausalitas dan korelasional antara variabel melalui pengujian hipotesis. Jenis Data Sekunder, sedangkan Teknik Pengumpulan Data Content Analysis atas Laporan Tahunan dan telaah dokumen. Metode Analisis Data dengan Pengujian statistik deskriptif, asumsi klasik, model analisis regresi sederhana dan Moderate Regression Analysis (MRA) serta Analisis Kualitatif. Berikut definisi operasional variabel yang digunakan dalam penelitian ini. 
Tabel 1

Ringkasan Definisi Operasional Variabel

\begin{tabular}{|c|c|c|c|}
\hline Variabel & Definisi Operasional & Pengukuran & Skala \\
\hline \multirow{2}{*}{$\begin{array}{l}\text { Independen: } \\
\text { Pengungkapan } \\
\text { tanggung jawab } \\
\text { sosial perusaha- } \\
\text { an (CSR) }\end{array}$} & Luas pengungkapan tanggung & 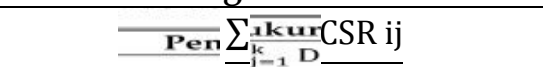 & Rasio \\
\hline & $\begin{array}{l}\text { jawab sosial dengan membanding- } \\
\text { kan jumlah pengungkapan yang } \\
\text { dilakukan dengan jumlah peng- } \\
\text { ungkapan yang diharapkan. }\end{array}$ & $\begin{array}{c}\operatorname{CSR}=\frac{\mathrm{K}}{\mathrm{K}} \\
(\mathrm{GRI}, 2013)\end{array}$ & \\
\hline $\begin{array}{l}\text { Independen: } \\
\text { Umur } \\
\text { perusahaan }\end{array}$ & $\begin{array}{l}\text { Umur perusahaan menunjukkan } \\
\text { bahwa perusahaan masih tetap } \\
\text { eksis dan mampu bersaing. }\end{array}$ & $\begin{array}{l}\text { Yaitu dihitung sejak tanggal } \\
\text { perusahaan tersebut tercatat } \\
\text { dibursa (Ansah, 2000). }\end{array}$ & Rasio \\
\hline $\begin{array}{l}\text { Independent: } \\
\text { Ukuran } \\
\text { perusahaan }\end{array}$ & $\begin{array}{l}\text { Merupakan ukuran atau besarnya } \\
\text { asset yang dimiliki perusahaan. }\end{array}$ & $\begin{array}{l}\text { Size }=\text { Log Total Asset } \\
(\text { Ramasamy et al., 2005) }\end{array}$ & Rasio \\
\hline $\begin{array}{l}\text { Dependen: } \\
\text { Kinerja keua- } \\
\text { ngan berbasis } \\
\text { akuntansi } \\
\text { (ROA) }\end{array}$ & $\begin{array}{l}\text { Kinerja keuangan diukur dengan } \\
\text { menggunakan salah satu rasio } \\
\text { keuangan profitabilitas, yaitu } \\
\text { ROA (Return On Asset) }\end{array}$ & $\begin{array}{l}\text { ROA }=\frac{\text { Laba Bersih Setelah Pajak }}{\text { Total Asset }} \\
(\text { Harmono, 2009) }\end{array}$ & Rasio \\
\hline $\begin{array}{l}\text { Dependen: } \\
\text { Kinerja } \\
\text { keuangan } \\
\text { berbasis pasar } \\
\text { (Tobin's Q) }\end{array}$ & $\begin{array}{l}\text { Tobin's Q merupakan nilai per- } \\
\text { usahaan dari sudut pandang pasar } \\
\text { yang menggambarkan persepsi } \\
\text { investor terhadap nilai pasar } \\
\text { perusahaan relative dengan nilai } \\
\text { bukunya. }\end{array}$ & $\begin{array}{c}Q=\frac{\text { MVE }+ \text { DEBT }}{\text { TA }} \\
\text { (Saraswati dan Hadiprajitno } \\
\text { 2012). }\end{array}$ & Rasio \\
\hline
\end{tabular}

Secara umum penelitian ini menggunakan program statistik dari SPSS versi 16.0 dengan alat analisisnya yaitu uji regresi linier berganda. Model regresi linier berganda adalah sebagai berikut:

$\mathrm{ROA}=\alpha+\beta 1 \mathrm{CRS}+\beta 2 \mathrm{Umur}+\beta 3 \mathrm{Ukuran}$ Dekom $+\beta 4$ Size $+\mathrm{e}$

$\mathrm{ROA}=\alpha+\beta 1 \mathrm{CRS}+\beta 2 \mathrm{Umur}+\beta 3 \mathrm{Ukuran}$

Dekom $+\beta 4$ Size $+\beta 5$ CSR * Umur + e .....(2)

$\mathrm{ROA}=\alpha+\beta 1 \mathrm{CRS}+\beta 2 \mathrm{Umur}+\beta 3 \mathrm{Ukuran}$ Dekom $+\beta 4$ Size $+\beta 6$ CSR * Ukuran Dekom $+\mathrm{e}$

$\mathrm{ROA}=\alpha+\beta 1 \mathrm{CRS}+\beta 2 \mathrm{Umur}+\beta 3 \mathrm{Ukuran}$ Dekom $+\beta 4$ Size $+\beta 6$ CSR * Size + e $\ldots . .(4)$

Uji interaksi sering disebut dengan Moderated Regression Analysis (MRA) merupakan aplikasi khusus regresi berganda linear dimana dalam persamaan regresinya mengandung unsur interaksi (perkalian dua atau lebih variabel independen) (Ghozali, 2012). Variabel perkalian antara CSR dengan Karakteristik Perusahaan (Umur), Ukuran Dekom dan Size yang merupakan variabel moderating.

\section{ANALISIS DAN PEMBAHASAN Hasil Uji Statistik}

Total sampel sesuai dengan kriteria sampel adalah 45 perusahaan, dengan jumlah data 135. Statistik deskriptif difokuskan kepada nilai maximum, minimum, rata-rata (mean) dan standar deviasi. Statistik deskriptif selengkapnya dapat dilihat pada tabel 3 berikut.

Dari tabel 3 dapat disimpulkan bahwa sebagian besar perusahaan manufaktur (52\%) sudah mengimplementasikan CSR. Nilai rata-rata umur perusahaan 16,93 menunjukkan bahwa besarnya kemampuan perusahaan untuk tetap eksis dan bersaing di pasar adalah sebesar $17 \%$. 
Tabel 3

Statistik Deskriptif

\begin{tabular}{lrrrrr}
\hline \hline & N & Minimum & Maximum & Mean & Std. Deviation \\
\hline CSR & 135 &, 21 &, 71 &, 5158 &, 09359 \\
Umur & 135 &, 00 & 32,00 & 16,9333 & 8,09477 \\
Ukuran Dekom & 135 & 1,00 & 11,00 & 4,2444 & 1,81399 \\
Size & 135 & 4,95 & 8,33 & 6,2498 &, 64020 \\
ROA & 135 & $-15,57$ & 65,72 & 8,1530 & 9,81359 \\
Q & 135 &, 01 & 7,11 & 1,6488 & 1,55515 \\
Valid N (listwise) & 135 & & & & \\
\hline
\end{tabular}

Sumber: Data Olah SPSS Versi 16.0

Besarnya kemampuan dekom melakukan pengendalian dan monitoring sangat minim adalah 4,24\%. Kemampuan perusahaan untuk memberikan keuntungan dari asset adalah sebesar 6,24\%. Kemampuan perusahaan dalam pemanfaatan asset untuk menciptakan laba yang diukur dengan ROA adalah sebesar $8,15 \%$ sedangkan nilai Tobin's Q adalah sebesar 1,64\%.

Semua variabel penelitian dan data yang digunakan dalam penelitian ini telah memenuhi uji asumsi klasik yaitu uji normalitas, uji multikolinearitas, uji autokorelasi dan uji heteroskedastisitas. Hasil perhitungan model regresi pertama diperoleh nilai Adjusted R Square untuk ROA adalah sebesar 15,4\%. Hal ini menunjukkan bahwa kinerja keuangan yang diukur dengan ROA dapat dijelaskan oleh variabel independen sebesar $15,4 \%$, sedangkan sisanya sebesar $84,6 \%$ dipengaruhi oleh variabel lainnya yang tidak diteliti, sedangkan nilai Adjusted
$\mathrm{R}$ Square untuk Tobin's $\mathrm{Q}$ adalah sebesar $12,4 \%$.

Hal ini berarti bahwa Tobin's Q dapat dijelaskan oleh variabel independen sebesar $12,4 \%$, sedangkan sisanya sebesar $87,6 \%$ dipengaruhi oleh variabel lain yang tidak diteliti. Dengan demikian ROA lebih dapat dijelaskan dengan variable independen penelitian ini dibandingkan dengan $\mathrm{Q}$.

Hasil uji regresi dapat dilihat pada tabel 5 dan 6 berikut. Berdasarkan tabel 6 maka model regresi linear berganda untuk kedua variable kinerja keuangan adalah sebagai berikut:

ROA $=-5,741+18,387$ CSR $+0,266$ Umur + 1,427Ukuran Dekom - 0,984Size + e

$\mathrm{Q}=-3,978+2,579$ CSR $+0,008$ Umur + 0,037Ukuran Dekom + 0,639Size + e

Untuk uji hipotesis 2, 3 dan 4 yang menggunakan variabel moderasi didasarkan pada uji regresi model 1.

Tabel 4

Hasil Uji R Square

\begin{tabular}{crrrr}
\hline Variabel $\mathbf{Y}$ & $\mathbf{R}$ & R Square & $\begin{array}{c}\text { Adjusted } \mathbf{R} \\
\text { Square }\end{array}$ & $\begin{array}{c}\text { Std. Error of the } \\
\text { Estimate }\end{array}$ \\
\hline ROA &, $424(\mathrm{a})$ &, 180 &, 154 & 9,02475 \\
$\mathbf{Q}$ &, $388(\mathrm{a})$ &, 151 &, 124 & 1,45513 \\
\hline
\end{tabular}

a Predictors: (Constant), Size, CSR, Umur, Ukuran Dekom Sumber: Data Olah SPSS Versi 16. 
Tabel 5

Persamaan Regresi 1a (ROA)

\begin{tabular}{|c|c|c|c|c|c|c|}
\hline \multirow{2}{*}{\multicolumn{2}{|c|}{ Model }} & \multicolumn{2}{|c|}{$\begin{array}{c}\text { Unstandardized } \\
\text { Coefficients }\end{array}$} & \multirow{2}{*}{$\begin{array}{c}\begin{array}{c}\text { Standardized } \\
\text { Coefficients }\end{array} \\
\text { Beta } \\
\end{array}$} & \multirow[t]{2}{*}{$\mathbf{t}$} & \multirow[t]{2}{*}{ Sig. } \\
\hline & & B & Std. Error & & & \\
\hline \multirow[t]{5}{*}{1} & (Constant) & $-5,741$ & 9,048 & &,- 635 &, 527 \\
\hline & CSR & 18,387 & 9,191 & 175 & 2,001 & ,048 \\
\hline & Umur & 266 & 102 & 219 & 2,595 & ,011 \\
\hline & Ukuran Dekom & 1,427 & ,577 & 264 & 2,472 & ,015 \\
\hline & Size &,- 984 & 1,606 &,- 064 &,- 612 & ,541 \\
\hline
\end{tabular}

a Dependent Variable: ROA

Tabel 6

Persamaan Regresi 1b (Q)

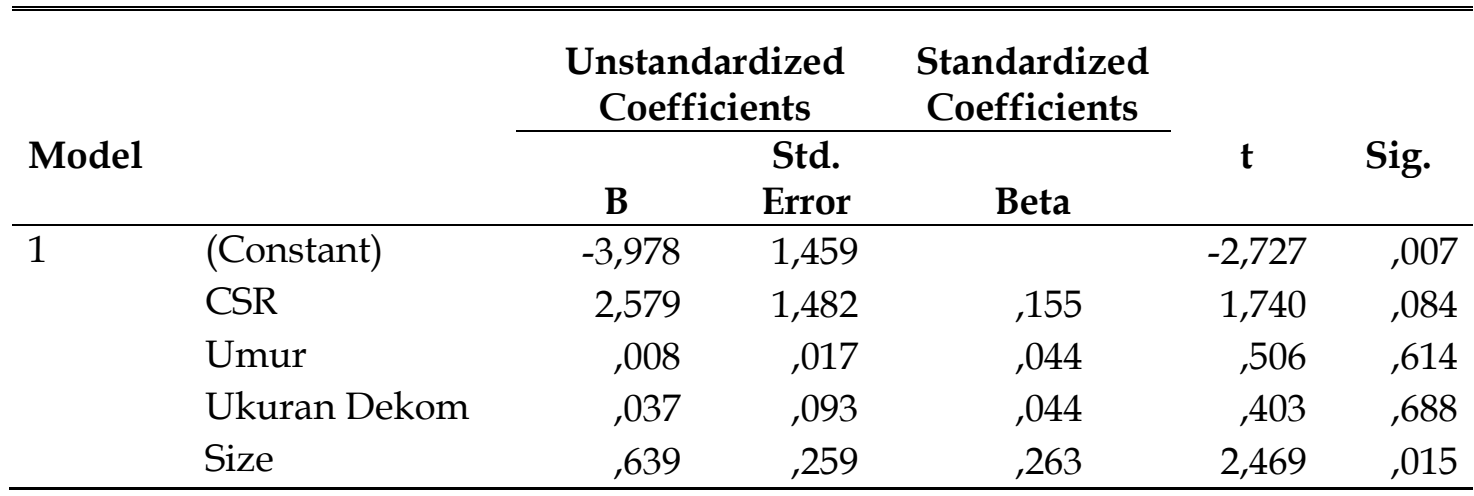

a Dependent Variable: Tobins'Q

Dari hasil uji statistik model 1, ROA sebagai variabel dependennya, maka nilai signifikansi untuk Size sebesar 0,541, yang lebih besar dari 0,05 sehingga dapat dikeluarkan dari model regresi (Santoso, 2012). Ini berarti bahwa uji H4a tidak dapat dilanjutkan uji statistiknya. Untuk hasil regresi dengan $Q$ sebagai variabel dependennya, maka semua variable independen bernilai signifikansi lebih dari 0,05. sehingga pengujian $\mathrm{H}_{2 b}, \mathrm{H}_{3 b}$ dan $\mathrm{H}_{4 b}$ tidak perlu dilakukan.

Artinya persamaan regresi 2, 3 dan 4 yang menguji variabel karateristik perusahaan sebagai variabel moderating terhadap hubungan CSR kepada kinerja keuangan (Q) tidak dapat dilanjutkan uji statistiknya (Santoso, 2012). Persamaan regresi 2 bertujuan untuk melihat apakah variabel Umur mampu memoderasi hubungan pengungkapan CSR dengan kinerja keuangan yang diukur dengan ROA. Hal ini dapat dilihat pada tabel 7. Dari tabel 7, dapat ditentukan persamaan regresi sebagai berikut:

$\mathrm{ROA}=\alpha+\beta 1 \mathrm{CSR}+\beta 2$ Umur $+\beta 3$ Ukuran Dekom $+\beta 4$ Size $+\beta 5$ CSR * Umur + e .....(2)

ROA $=-2,462+8,100$ CSR $-0,074$ Umur + 0,991Ukuran Dekom - 2,87Size + 0,635CSRUmur..

Persamaan regresi 3 bertujuan untuk melihat apakah variabel Ukuran Dekom mampu memoderasi hubungan pengungkapan tanggung jawab sosial perusahaan (CSR) dengan kinerja keuangan (ROA). Hal ini dapat dilihat pada tabel 8. 
Tabel 7

Persamaan Regresi 2 (ROA)

\begin{tabular}{|c|c|c|c|c|c|c|}
\hline \multirow{3}{*}{\multicolumn{2}{|c|}{ Model }} & \multicolumn{2}{|c|}{$\begin{array}{l}\text { Unstandardized } \\
\text { Coefficients }\end{array}$} & \multirow{3}{*}{$\begin{array}{c}\begin{array}{c}\text { Standardized } \\
\text { Coefficients }\end{array} \\
\text { Beta }\end{array}$} & \multirow{3}{*}{$\mathbf{t}$} & \multirow{3}{*}{ Sig. } \\
\hline & & & Std. & & & \\
\hline & & B & Error & & & \\
\hline \multirow[t]{6}{*}{1} & (Constant) & $-2,462$ & 7,883 & &,- 312 & ,755 \\
\hline & CSR & 8,100 & 8,144 & 077 & ,995 & 322 \\
\hline & Umur &,- 074 & 103 &,- 061 &,- 713 & 477 \\
\hline & Ukuran Dekom & 991 &, 506 & 183 & 1,957 & ,052 \\
\hline & Size & -287 & 1,401 & -019 &,- 205 & 838 \\
\hline & Interaksi CSR.Umur & 635 & ,097 &, 551 & 6,553 &, 000 \\
\hline
\end{tabular}

Sumber: Data Olah SPSS Versi 16.0

Tabel 8

Persamaan Regresi 3 (ROA)

\begin{tabular}{llrrrrrr}
\hline \hline \multirow{2}{*}{ Model } & & \multicolumn{2}{c}{$\begin{array}{c}\text { Unstandardized } \\
\text { Coefficients }\end{array}$} & \multicolumn{2}{c}{$\begin{array}{c}\text { Standardized } \\
\text { Coefficients }\end{array}$} & \multirow{2}{*}{ t } & \multirow{2}{*}{ Sig. } \\
\cline { 3 - 5 } & & \multicolumn{1}{c}{ B } & Std. Error & \multicolumn{1}{c}{ Beta } & & \\
\hline 1 & (Constant) & 1,977 & 15,577 & &, 127 &, 899 \\
& CSR & 6,155 & 22,084 &, 059 &, 279 &, 781 \\
& Umur &, 287 &, 109 &, 237 & 2,647 &, 009 \\
& Ukuran Dekom &,- 264 & 2,833 &,- 049 &,- 093 &, 926 \\
& Size & $-1,174$ & 1,640 &,- 077 &,- 716 &, 475 \\
& Interaksi & 2,927 & 4,802 &, 380 &, 609 &, 543 \\
\hline & CSRUkuranDekom & & & & &
\end{tabular}

Dependent Variabel : ROA

Sumber: Data Olah SPSS Versi 16.0

Dari tabel 8, dapat ditentukan persamaan regresi sebagai berikut:

$\mathrm{ROA}=1,977+6,155 \mathrm{X}_{1}+0,287 \mathrm{X}_{2}-0,264 \mathrm{X}_{3}-$ $1,174 X_{4}+2,927 X_{1} X_{3}$

\section{Pembahasan}

Pengaruh Pengungkapan CSR Terhadap Kinerja Keuangan (ROA dan Q)

Hipotesis pertama dalam penelitian ini adalah pengungkapan CSR berpengaruh terhadap kinerja keuangan (ROA dan $\mathrm{Q})$. $\mathrm{H}_{1 . a}$ pada tabel 5 menunjukkan nilai t CSR 2,001 dengan signifikansi 0,048 < 0,05 maka CSR berpengaruh positif terhadap ROA. Artinya, pengungkapan CSR cukup tinggi pada perusahaan manufaktur yang terdaftar di BEI dan mampu meningkatkan kinerja keuangan (ROA). Hasil ini sesuai dengan Wu (2006), yang menemukan bahwa ke- baikan perusahaan melalui CSR ditanggapi positif oleh masyarakat yang tercermin dari adanya hubungan signifikan dan positif antara kinerja sosial dan kinerja keuangan. Anwar et al., (2010) menemukan hubungan yang signifikan antara indeks kinerja sosial dan kinerja ekonomi seperti ROA. Choi et al. (2010), menyatakan bahwa CSR berpengaruh positif dan signifikan terhadap kinerja keuangan (ROE, ROA, dan Tobin's Q) yang dihasilkan perusahaan di Korea.

Hasil uji hipotesis $H_{1 . b}$ pada tabel 6 menunjukkan bahwa signifikansi yang lebih besar dari 0,05, dapat disimpulkan bahwa pengungkapan CSR bukan faktor yang menentukan kinerja keuangan yang diukur dengan Tobin's Q. Penelitian ini tidak mendukung $\mathrm{H}_{1 . b}$. Hal ini menunjukkan bahwa kualitas pengungkapan CSR pada perusaha- 
an sampel yang terdaftar di BEI untuk tahun 2011-2014 sangat rendah dan belum sesuai standar yang dikeluarkan oleh GRI. Hasil ini sesuai dengan yang disampaikan Nurlela dan Islahuddin (2008), yaitu kualitas pengungkapan CSR di dalam perusahaan menjadi faktor yang menyebabkan praktik CSR tidak berpengaruh terhadap nilai perusahaan (Tobin's Q).

Dengan demikian kinerja keuangan yang digunakan berdasarkan accounting based measure (ROA) akan berbeda hasilnya dengan market based measure (Tobin's Q). Accounting based measure memberikan hasil yang lebih baik dari pada market based measure. Hal ini menunjukkan bahwa pelaku pasar di BEI belum merespon dengan baik informasi CSR yang ada dalam laporan tahunan perusahaan sampel. Dengan kata lain temuan ini mengindikasikan bahwa semakin banyak informasi CSR yang diungkapkan oleh perusahaan tidak dapat meningkatkan kinerja keuangan berdasarkan pasar (yang diukur dengan Q). Hal ini mungkin disebabkan masih banyak faktor lain yang dapat mempengaruhi Tobin's $Q$ yang tidak dikaji dalam penelitian ini. Perlu kepedulian pemerintah atau dewan standar untuk mengatur pengungkapan CSR sehingga informasi CSR yang dikeluarkan perusahaan lebih direspon oleh pelaku pasar.

Pengaruh Umur Perusahaan Dalam Hubungan Pengungkapan CSR dan Kinerja Keuangan (ROA dan Q)

Uji hipotesis kedua tentang moderasi variable umur perusahan terhadap hubungan CSR dan kinerja keuangan dapat dilihat pada tabel 7 , dimana nilai $t$ sebesar 6,553 dengan signifikansi lebih kecil dari 0,05 $(0,000<0,05)$. Jadi variabel umur perusahaan dapat mempengaruhi hubungan antara pengungkapan CSR dengan kinerja keuangan (ROA).

Hasil ini tidak sejalan dengan Kuntari dan Sulistyani (2007); Luthan (2010) yang mengatakan bahwa variabel umur perusaha- an tidak memiliki pengaruh signifikan terhadap hubungan kinerja keuangan dengan tanggung jawab sosial. Dengan kata lain semakin tua umur perusahaan maka tidak mampu meningkatkan kinerja keuangan (ROA), dan pengungkapan CSR yang dibuat akan semakin sedikit. Namun, Baron (2007) menyatakan, ketika sebuah perusahaan berkembang dan para akuntannya belajar lebih banyak masalah pertumbuhan, menyebabkan penundaan yang luar biasa dapat diminimalisasikan. Akibatnya perusahaan mapan yang memiliki umur lebih tua cenderung lebih terampil dalam pengumpulan, pemprosesan dan menghasilkan informai ketika diperlukan karena pengalamannya.

Pengaruh Ukuran Dewan Komisaris Terhadap Hubungan Pengungkapan CSR Dengan Kinerja Keuangan (ROA dan Q)

Hasil pengujian untuk $\mathrm{H}_{3 . a}$ dapat dilhat pada tabel 8. Hasil ini menunjukkan nilai signifikan lebih besar dari 0,05 $(0,543>0,05)$, maka dapat disimpulkan bahwa variabel ukuran dewan komisaris tidak mampu pengaruhi hubungan pengungkapan CSR terhadap kinerja keuangan (yang diukur dengan ROA). Hasil temuan ini tidak konsisten dengan hasil penelitian yang dilakukan oleh Jamali et al. (2008) menyatakan bahwa semakin besar jumlah anggota dewan komisaris, maka akan semakin mudah untuk mengendalikan CEO dan monitoring yang dilakukan akan semakin efektif. Dikaitkan dengan pengungkapan CSR, maka tekanan terhadap manajemen juga akan semakin besar untuk melakukan pengungkapan. Jika manajemen melakukan pengungkapan CSR dengan baik maka hal ini akan berdampak terhadap kinerja keuangan perusahaan tersebut.

Berdasarkan review penelitian sebelumnya, hasil penelitian ini mendukung penelitian yang dilakukan oleh Jamali et al. (2008), Haniffa dan Cooke (2005), yaitu salah satu argumen menyatakan bahwa makin banyaknya personel yang menjadi dewan komisaris dapat berakibat pada makin 
buruknya kinerja yang dimiliki perusahaan. Hal tersebut dapat dijelaskan dengan adanya agency problems, yaitu dengan makin banyaknya anggota dewan komisaris maka badan ini akan megalami kesulitan dalam menjalankan perannya, diantaranya kesulitan dalam berkomunikasi dan mengkoordinir kerja dari masing-masing anggota dewan itu sendiri, kesulitan dalam mengawasi dan mengendalikan tindakan dari manajemen, serta kesulitan dalam mengambil keputusan yang berguna bagi perusahaan.

Dengan demikian, ukuran dewan komisaris tidak dapat mempengaruhi hubungan pengungkapan CSR dengan kinerja keuangan. Untuk perusahaan sampel dapat disimpulkan bahwa dewan komisaris belum menjalankan fungsi monitoring dan kontrol perusahaan.

\section{SIMPULAN DAN SARAN Simpulan}

Berdasarkan pembahasan yang teah dilakukan berikut beberapa simpulan penelitian yang bisa diambil. (1) Variabel pengungkapan CSR berpengaruh secara signifikan terhadap kinerja keuangan yang diukur dengan ROA, sedangkan terhadap kinerja keuangan yang diukur dengan Tobin's Q memberikan pengaruh yang tidak signifikan. Pelaku pasar belum merespon dengan baik informasi CSR yang diberikan dalam laporan tahunan; (2) Umur perusahaan dapat memoderasi hubungan pengungkapan CSR dengan kinerja keuangan yang diukur dengan ROA; (3) Variabel ukuran dewan komisaris yang diproksikan oleh jumlah anggota dewan komisaris, sebagai variabel moderating tidak dapat mempengaruhi hubungan pengungkapan CSR dan kinerja keuangan baik dengan ROA maupun Tobin's Q; (4) Moderasi ukuran perusahaan dengan kinerja sosial tidak dapat memperkuat hubungan pengungkapan CSR dan kinerja keuangan baik dengan ROA maupun dengan Tobin's Q). Artinya, interaksi ukuran perusahaan dengan pengungkapan CSR tidak dapat mem- perkuat hubungan pengungkapan CSR dan kinerja keuangan.

\section{Saran}

Saran yang dapat digunakan dalam penelitian mendatang yaitu: (1) Penelitian selanjutnya perlu mempertimbangkan sampel yang lebih luas, yang mencakup semua jenis perusahaan yang terdaftar di BEI, sehingga akan terlihat perbedaan dari masing-masing industri; (2) Analisis regresi yang digunakan dalam penelitian ini menghasilkan $\mathrm{R}$ Square yang rendah dalam menjelaskan variabel dependen, oleh karena itu, terdapat kemungkinan untuk menghasilkan variabel-variabel baru ke dalam penelitian berikutnya; (3) Peneliti selanjutnya dapat mempertimbangkan variabel lain yang memiliki pengaruh lebih besar terhadap kinerja keuangan seperti mekanisme Good Corporate Governance (GCG); (4) Perlu dikaji lebih lanjut indicator CSR yang dilakukan perusahaan; (5) Penelitian ini lebih menitik beratkan pada sisi manajemen (perusahaan) karena menggunakan data laporan tahunan. Jadi penelitian ini hanya mengevaluasi berdasarkan pada data yang disediakan oleh internal perusahaan. Dianjurkan penelitian selanjutnya untuk meneliti dari sisi stakeholders eksternal atau campuran antara kedua sisi (manajemen dan stakeholders eksternal). Penelitian juga belum melihat secara mendalam tentang efektifias praktik CSR serta dimensi ukuran efektifitas, untuk itu penelitian selanjutnya disarankan untuk meneliti wilayah tersebut; (6) Akuntabilitas lewat keterbukaan informasi pengorbanan sosial yang telah dilakukan perusahaan tetap harus dijalankan. Bila perlu, tidak hanya melibatkan satu media pertanggungjawaban (annual report) melainkan harus diperluas cakupannya. Pengungkapan atau transformasi pertanggungjawaban sosial perusahaan mengandung information content. Karena hal ini memiliki kontribusi besar dalam membangun opini, membangun image, mendukung competitive advantage bahkan memiliki kandungan informasi bagi 
pemegang saham, investor dan calon investor. Meskipun terdapat beberapa stakeholders, termasuk calon investor yang masih tak acuh terhadap CSR tersebut. Hal itu dapat dilihat dari hasil pengujian pengaruh antara pengungkapan sosial terhadap kinerja keuangan yang tidak signifikan, namun ada hubungan antara tanggung jawab sosial yang diproksikan sebagai kinerja sosial dan kinerja keuangan; (7) Hingga kini belum ada kesepakatan standar pelaporan CSR yang dapat dijadikan acuan bagi perusahaan dalam menyiapkan laporan CSR. Cakupan standar yang ada sudah cukup komprehensif, namun, belum ada laporan yang dapat mengikhtisarkan dampak kegiatan perusahaan terhadap sosial dan lingkungan sehingga akan menyulitkan stakeholders dalam mengevaluasi efektivitas kegiatan CSR perusahaan. Pemerintah selaku pemegang otoritas, seharusnya menetapkan seperangkat aturan tentang definisi, prosedur, cakupan, tingkat, sistem evaluasi dan metode tanggung jawab sosial yang harus dilakukan oleh perusahaan. Hal seperti itu penting, untuk dijadikan acuan perusahaan dalam melakukan CSR terhadap masyarakat dan lingkungan. Disamping itu, dari sisi stakeholders, terdapat pegangan dalam melakukan kontrol dampak lingkungan yang mungkin timbul akibat industrialisasi.

\section{Keterbatasan}

Salah satu indikator CSR adalah pengungkapan sustainability perusahaan. Subjektivitas dalam pengukuran pengungkapan CSR tidak dapat dihindari sehingga kemungkinan terjadi bias dalam pengukuran pengungkapan CSR .

\section{DAFTAR PUSTAKA}

Adams, R. B. dan H. Mehran. 2005. Corporate Performance, Board Structure and Its Determinants in the Banking Industry. EFA 2005 Moscow Meetings, August 8, 2005. (http://www.ssrn.com)

Anwar, S., S. Haerani, dan G. Pagalung. 2010. Pengaruh Pengungkapan Corporate Social Responsibility Terhadap Kinerja
Keuangan Perusahaan dan Harga Saham. E-jurnal. Universitas Hasanuddin, http://pasca.unhas.ac.id/jurnal/files/38fa14eea5a 58ca1179442fce7e9d761.pdf

Allouche, J. dan P. Laroche. 2005. A MetaAnalytical Investigation of The Relationship between Corporate Social and Financial Performance, Revue de Gestion des Ressources Humaines 57: pp 18.

Al-Tuwaijri, S. A., T. E. Christensen, dan K. E. Hughes II. 2004. The Relation among Environmental Disclosure, Environmental Performance and Economic Performance: a Simultaneous Equations Approach. Accounting, Organization and Society 29(5-6): 447-471.

Baron, D. P. 2007. Managerial Contracting and Corporate Social Responsibility. Journal of Public Economics 92(1-2): 268288.

Choi, J. S., Y. M. Kwak, dan C. Choe. 2010. Corporate Social Responsibility and Corporate Financial Performance: Evidence from Korea. Australian Journal Management 35(3): 291-311.

Daniri, A. 2008. Menuju Standardisasi CSR. http://www.madani-ri.com// standarisasi-tanggung-jawab-sosialperusahaan. Diakses tanggal 17 Januari 2008.

Erica, Y., C. V. Staden, dan S. Cahan. 2011. Corporate Social Responsibility Reporting and Earnings Management: The Role of Political Costs. Australasian Accounting Business and Finance Journal 5(3): 1733.

Ghozali, I. dan A. Chariri. 2007. Teori Akuntansi. Badan Penerbit Universitas Diponegoro. Semarang.

Ghozali, I. 2012. Aplikasi Analisis Multivariate Dengan Program IBM SPSS 20. Edisi 6. Badan Penerbit Universitas Diponegoro. Semarang.

Global Reporting Initiative. 2013. G4 Guidelines-Reporting Principles and Standard Disclosures. GRI. Amsterdam.

Guthrie, J. dan L. D. Parker. 1989. Corporate Social Reporting: A Rebuttal of Legiti- 
macy Theory. Accounting and Business Research 19(76): 343-352.

Harmono. 2009. Manajemen Keuangan. PT. Bumi Aksara. Jakarta.

Jamali, D., A. M. Safieddine, dan M. Rabbath. 2008. Corporate Governance and Corporate Social Responsibility Synergies and Interrelationships. An International Review 16(5): 443-459.

Jumingan. 2006. Analisis Laporan Keuangan. Bumi Aksara. Surakarta.

Haniffa, R.M. dan T. E. Cooke. 2005. The Impact of Culture and Governance on Corporate Social Reporting. Journal of Accounting and Public Policy 24(5): 391430.

Hubbard, G. 2009. Measuring Organizational Performance: Beyond the Triple Bottom Line. Business Strategy and the Environment. 18(3): 177-191.

Kolk, A. 2008. Sustainability, Accountability and Corporate Governance: Exploring Multinationals' Reporting Practices. Business Strategy and Environment 17(1): 1-15.

Kuntari, Y. dan A. Sulistyani. 2007. Pengaruh Karakteristik Perusahaan Terhadap Pengungkapan Tanggung Jawab Sosial dalam Laporan Tahunan Perusahaan Indeks Letter Quality (LQ 45) Tahun 2005. ASET 9(2): 494 -515.

Luthan, E. 2010. Keterkaitan Antara Corporate Social Responsibility (CSR) dan Good Corporate Governance (GCG) dalam Meningkatkan Kinerja Perusahaan. UNPAD PRESS.

Lukas, S. dan B. Basuki. 2015. The Implementation of Good Corporate Governance and Its Impact on The Financial Performane of Banking Industry Listed in IDX. The International Journal of Accounting and Business Society 23(1): 4772.

McBarnet, D., A. Voiculescu, dan T. Campbell. 2007. The New Corporate Responsibility: Corporate Social Responsibility and the Law, Cambridge University Press. Melbourne, Australia.
Morland, M. P. 2006. Triple Bottom Line Reporting as Social Grammar: Integrating Corporate Social Responsility and Corporate Codes of Conduct. Business Ethics: A European Review 15(4): 352-364.

Nurlela, R. dan Islahuddin. 2008. Pengaruh Corporate Social Responsibility Terhadap Nilai Perusahaan Dengan Prosentase Kepemilikan Manajemen Sebagai Variabel Moderating. Simposium Nasional Akuntansi XI Pontianak.

Orlitzky, M., F. L. Schdmit, dan S. L. Reynes. 2003. Corporate Social and Financial Performance: A Meta-analysis. Organization Studies 24(3): 403-441.

Ramasamy, B., D. Ong, dan M. C. H. Yeung. 2005. Firm Size, Ownership and Performance in the Malaysian Palm Oil Industry. Asian Academy of Management Journal of Accounting and Finance 1: 81104.

Saleh, M., N. Zulkifli, dan R. Muhamad. 2008. An Empirical Examination of the Relationship between Corporate Social Responsibility Disclosure and Financial Performance in an Emerging Market. 16th Annual Conference on Pacific Basin Finance Economics Accounting Management (PBFEAM) Malaysia.

Santoso, S. 2012. Panduan Lengkap SPSS Versi 20. Penerbit PT Elex Media Komputindo. Jakarta.

Saraswati, R. dan B. Hadiprajitno. 2012. Pengaruh Corporate Governance pada Hubungan Corporate Social Responsibility dan Nilai Perusahaan Manufaktur yang Terdaftar di BEI. Jurnal Akuntansi dan Auditing 9(1): 86-96.

Steiner, J. F. dan G. A. Steiner. 2006. Business, Government \& Society: A Managerial Perspektif. McGraw Hill Corp. New York.

Sutrisno, H. 2012. Manajemen Keuangan: Teori Konsep dan Aplikasi. Penerbit Ekonisia. Yogyakarta.

Undang-Undang Republik Indonesia Nomor 40 Tahun 2007 tentang Perseroan Terbatas. 
Valentina, Y. K. 2013. Pengaruh Komponen Modal Intelektual Terhadap Kinerja Keuangan Dengan Ukuran Perusahaan Sebagai Variabel Moderating Pada Perusahaan Perbankan Di BEI. Thesis. Universitas Andalas. Padang.

WBCSD (World Bussines Council For Suistanable Development). 2008. Corporate Social Responsibility: Meeting Changing Expectations. http://www. wbcsd.org. Diakses April 2015.

Wright, P., M. Kroll., A. Mukhreji, dan M. L. Pettus. 2009. Do the Contingencies of External Monitoring, Ownership Incentives, or Free Cash Flow Explain Opposing Firm Performance Expectations?. Journal of Management and Governance 13(3): 215-243.
Wu, M. L. 2006. Corporate Social Performance, Corporate Financial Performance, and Firm Size: A Meta Analysis. Journal of American Academy of Business 8(1): 163-171.

Yosefa S. dan L. S. Wondabio. 2007. Pengaruh CSR Disclosure Terhadap Earnings Response Coefficient (Studi Empiris pada Perusahaan yang Terdaftar di Bursa Efek Jakarta). Seminar Nasional Akuntansi X Makasar.

Yayasan KEHATI. 2015. http://www.kehati. or.id/about/sri-kehati.html. Diakses tanggal 3 Februari 2015. 